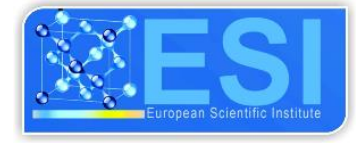

10 years ESJ

Special edition

\section{Joanna Pfaff-Czarnecka}

Bielefeld University, Germany

Submitted: 31 August 2020

Accepted: 02 November 2020

Published: 31 December 2020

Corresponding author:

Joanna Pfaff-Czarnecka

DOI: $10.19044 /$ esj.2020.v16n39p113

cc) Copyright 2020 Joanna Pfaff-Czarnecka Distributed under Creative Commons BY-NC-ND 4.0 OPEN ACCESS
From 'identity' to 'belonging' in social research: Plurality, social boundaries, and the politics of the self

\section{Abstract}

This text develops a theory of belonging critically building upon identity-research while doing more justice to the dynamic nature of social constellations and to the multipositionality of social actors. The concept of 'belonging' is introduced as a combination of commonality, mutuality, and attachments. A vital opposition is made between the collective constellations of belonging and the individual navigations through multiple collective assemblages during the life course. It is argued that these navigations entail tackling manifold forms of boundary dynamics as collective belonging creates regimes that guard collectivities against the outsiders and also against the members' attempts to abandon 'their' collectivities. The analysis draws upon ethnicity research, immigration research and globalisation research, i.e. in fields where issues of belonging are as vital as they are challenged, and therefore, they are often politicized. Rather than taking a specific collective belonging for granted, e.g. ethnic, religious or national, this contribution addresses the situated nature of individual positionings, the possibility of combining different dimensions of belonging, and the necessity to belong together in contemporary societies.

Keywords: identity, belonging, social boundaries, plurality, collectivities, politics of the self 


\section{Introduction}

During his appeal hearing at the regional court in Dresden, Germany, in July 2009, Alex Wiens, a right-wing extremist of Russian-German origin attacked Marwa El-Sherbini with a knife, stabbing her to death. Marwa ElSherbini, a hijab-wearing 33 year-old academic of Egyptian origin - had taken him to court for abusing her during an encounter on a children's playground in Dresden. Before killing her on the court's premises, Alex Wiens asked Marwa El-Sherbini what on earth she was doing in Germany. He also confronted the authorities present in the courtroom, asking why, in the aftermath of 9/11, Muslims were not deported in their entirety to where they came from. "I could not understand,"- a direct quotation from his statement during the subsequent murder trial in November 2009 - "why she came to Germany, to this potentially unfaithful country that many Muslims hold in contempt. I (Alex) came to Germany because I have German roots and therefore this is my original home. I (Alex) could not understand" - and here comes the sentence that I find particularly striking - "... I could not understand why and how she could feel at home, here in Germany".

Three facets of this testimony are in the forefront of this article ${ }^{1}$. First, the importance of feeling at home. Currently, discourses of home and belonging are abound in public communication and they increasingly inspire academic research. Given its current attraction, it will be the aim of this text to reflect upon the concept of belonging and to propose analytical tools for capturing its salience. The empirical backdrop of this inquiry will consist mostly of Western immigrant contexts, but this reflection is meant to accommodate other social constellations as well. Second, the heavily and emotionally charged quest to belong is perennially impeded by others and systemically restricted. When she was murdered, Marwa El-Sherbini was ultimately denied making Germany her home. Alex Wiens - as can be inferred - could not imagine feeling at home in Germany when people like Marwa felt comfortable there. Belonging is thus an object of continuous negotiations between individuals and collectivities. This results in tensions and accommodations as well as an on-going process of setting, transcending, and blurring social boundaries. In order to understand belonging, it is crucial to know how it evolves within the protective confines of a specific life-world and

\footnotetext{
${ }^{1}$ Some ideas underlying this article were jointly developed together with Gérard Toffin (see the jointly written 'Introduction: Belonging and Multiple Attachments in Contemporary Himalayan Societies', Pfaff-Czarnecka and Toffin (2011)). Nevertheless, this is a novel approach, going far beyond the scope of the previous text, concentrating on Western immigrant societies, and considering individual aspects of belonging in particular. The author should like to thank Peter Geschiere, Lara Jüssen, Raphael Susewind and Richard Wartenweiler for their useful comments on earlier drafts of this text.
} 
how it is restricted within asymmetric power relations between those included and those remaining outside - with the modalities of inclusion and exclusion being two sides of the same coin (Luhmann 1997).

Third, Alex Wien's suspicion that an Egyptian Muslim could feel at home in Germany reveals - unintentionally - that it is possible to belong to a new social place when one's origins are elsewhere, and that it is possible to belong when one's identity (in this case, religious identity) does not conform to the national mainstream. We need to distinguish, therefore, between 'identity' and 'belonging'. Both concepts are often used interchangeably which is empirically confusing and analytically wrong. Would it serve a purpose to introduce the new term 'belonging' into social research if the old 'collective identity' was enough?

It is obvious that it wasn not, and that it is not only important to distinguish both terms analytically, but also to delve into the implications of this distinction for envisaging the possibilities of living together in the transnationalised contemporary world. As will be argued here, the concept of belonging, while taking up important preoccupations of the identity-concept, does more justice to the complexities, dynamics, and subtleties of human interrelating, to its situative and processual character than that of 'collective identity'.

This analysis develops a theory of belonging by drawing upon the author's empirical research conducted over the last four decades. The different phases of research always centered on collective orderings, boundary dynamics and the tension between individual freedom and the safety collectivites can offer to their members: caste-system and ethnicity formation in Nepal (see especially Pfaff-Czarnecka 1989; Pfaff-Czarnecka et al. 1999; Pfaff-Czarnecka et al. 2007; Gellner et al. 2008); accommodation of religious difference in middle European immigration societies (see especially PfaffCzarnecka 2009); critical social movements (see especially Pfaff-Czarnecka 2007; Gerharz and Pfaff-Czarnecka 2017) and globalisation of social spaces under the conditions of mobility (see especially Toffin and Pfaff-Czarnecka 2014). Thus, methodologically, the theory of belonging presented here builds a bridge for the previous analyses of collective constellations.

\section{What is belonging?}

What is belonging? To put it briefly: belonging is an emotionallycharged social location. People belong together when they share values, relations, and practices (Anthias 2006: 21). Belonging is a central dimension of life that is easily felt and tacitly experienced and very difficult to capture through analytical categories. Nevertheless, given the growing scholarly interest in this notion, it is worth trying to do so. In my view, belonging as an emotionally charged social location combines (1) perceptions and 
performances of commonality; (2) a sense of mutuality and more or less formalized modalities of collective allegiance, and (3) material and immaterial attachments that often result in a sense of entitlement. How these dimensions come to intersect, that is "when do we belong?", is an empirical question that can be explored once we have agreed on their centrality for grasping this notion.

Before proceeding further, it is important to differentiate between the individual's relation to a collective, on the one hand, and collective belonging, on the other. The German language makes a clear-cut distinction here that is not immediately discernible in the English word 'belonging'. The German term Zugehörigkeit denotes an individual's belonging to a collective (as does the French term 'appartenance' - that with its connotation 'à part' pinpoints a tension inherent in belonging, namely a distance between the self and a wecollective); whereas Zusammengehörigkeit stands for 'togetherness'. This distinction becomes of interest when one shifts the perspective from group dynamics geared at maintaining the collective status quo to a consideration of an individual's embeddedness in a collective, e.g. seeking access to it or trying to abandon it. While distinguishing 'belonging with' (Zusammengehörigkeit) from 'belonging to' (Zugehörigkeit), this text starts with the former - that ideally combines commonality, mutuality and attachment.

\section{Commonality}

'Commonality' is a perception of sharing, notably, sharing a common lot as well as cultural forms (language, religion, and lifestyle), values, experiences, and memory constructions. It is individually felt and embodied while collectively negotiated and performed. Commonality is often perceived through a social boundary-horizon that helps discern between the insiders and the outsiders. It thus relies on categorisations, mental checkpoints, everyday life distinctions, and public representations that often buttress the collective boundary-maintenance (Migdal 2004). This is precisely where commonality is likely to attain the form of collective identity that requires the other / the outside for engendering a perception of internal sameness. But we must not restrict our understanding of 'commonality' to 'collective identity'.

\section{Excursion: reaching beyond the lens of 'identity constructions'}

Human preoccupations with 'identity' - be it collective activism, the language used in everyday talk, or even academic research and analysis - have been inundated by the individual and collective aspirations and resulting positionings, normative considerations and the actions derived from this notion (Jenkins 1996). On the one hand, 'identity' seems to have acquired a natural property, becoming essentialized and reified, by being so extensively invoked during the past decades. While on the other hand, the incredible boom 
of this term has instigated a great deal of critique, that was best formulated by Brubaker and Cooper (2000). In their seminal, 'Beyond "identity", they make a number of important observations: first, the term 'identity' has become so ubiquitous, combining 'categories of practice' with 'categories of analysis', that it carries a huge number of connotations. "Identity," they argue, "tends to mean too much (when understood in a strong sense), too little (when understood in a weak sense), or nothing at all (because of its sheer ambiguity)" (2000: 1). Second, given the substantial range in the meanings used by actors and by scholars, the central connotations of this term can clash with one another as is the case with essentialising vis-à-vis constructivist approaches. Third, 'collective identity' transports homogenising notions of commonality and it endorses methodological ethnicization by delineating clear-cut collective boundaries of the social.

Most important is Brubaker's and Cooper's contention that 'identity' does not do justice to the full range of human forms shaped by commonality, mutuality and affiliations / attachments such as self-understanding or connectedness. Still, to suggest abanding the term 'identity' would be to enter into a struggle against windmills. It is more fruitful, therefore, to sharpen the analytical tools when venturing into the preoccupation with 'belonging' - a term that is more and more present in everyday use and that recently has become the object of a rapidly growing number of academic inquiries. The term does not have more analytical precision than that of 'identity', but capturing this term will help scholars to uncover the multiple, subtle and shifting modalities of forging and thinking about the collective dimensions of social life and the dynamic nature of social boundary-making.

It is important to highlight some major differences between 'identity' and 'belonging': 'Identity' is a categorical concept while 'belonging' combines categorisation with social relations. Identity is relational in the sense that it positions itself vis-à-vis the other. Belonging's relationality consists in forging and maintaining social ties and in buttressing commitments and obligations. Identity caters to dichotomous characterisations of the social while belonging rather highlights its situatedness and the multiplicity of parameters forging commonality, mutuality, and attachments. Identity relies on sharp boundary-drawing, particularism, and is prone to buttressing social divisiveness. Theorists may argue otherwise, for instance deploying the concept of identification that, unlike 'identity', entails situative and processual connotations; at the same time, identity politics have time and again revealed the exclusionary properties entailed in this notion. As has often been the case, the politics of belonging (see also below) are equally prone to affecting social exclusion as well as the opposite - widening borders, incorporating former outsiders, and defining new common grounds. This is precisely one of the 
reasons why the notion of belonging currently enjoys growing popularity in migration research.

Coming back to the discussion of commonality, one can infer that the term 'identity' highlights homogeneity of any given collective unit, whereas 'belonging' stresses commonness, but not necessarily sameness. Commonness tends to build upon a common cultural denominator, but it can also be created anew and re-shaped. The former German President Christian Wulff created quite an uproar when he expressed his conviction that Islam has a place in Germany ("Islam gehört zu Deutschland"). This statement is a perfect example of future-oriented possibilities in forging belongingness by incorporating new elements into the existing parameters of togetherness. In this vein, one important aspect of belonging is the commonality of purpose. For this reason, important characteristics of commonness entailed in the concept of belonging are mutuality, commitment and 'something' that is collectively at stake. The commonality entailed in belonging can be conceived by actors that especially relate to the past and, therefore, caters to nostalgia (see Geschiere 2009), but it can also be future-oriented - as Kannabiran claims, seeing not only the possibilities of being, but also of becoming in 'belonging'. As will be discussed below, the politics of belonging often entail a visionary element geared toward re-shaping the individual or collective social location. By contrast, the politics of identity claim an established collective narrative that seeks its political realisation. The dynamic properties of belonging are entailed in its multidimensional composition; in the 'thickness' of this term.

Commonality is a multi-layered condition, but the academic focus on collective identities has narrowed down its understanding. The concept of belonging underlines that people share significantly more than merely common identity markers. Belonging together - whether sharing collective identity or not - means sharing experience and of what goes without saying, the tacit self-evidence of being, jointly taking things for granted and sharing common knowledge and meanings. It is important to stress this point because shared meanings undergo continuous change. Belonging evolves in social life worlds where collective knowledge reservoirs are perennially recreated in social interactions. They are realised in social practices, in established modalities of negotiation, conflict, compromise and accommodation, and also in a continuous overt and covert reflection on the validity of norms that persist in a given social world. Shared are the continuous negotiations over any social life world's modalities as habitualised, institutionalised and legitimized. They can crystallise in common boundary perceptions through identity politics, but also open up and blur social boundaries (Zolberg and Long, 1999). 


\section{Mutuality}

Shared understandings significantly buttress the sense of mutuality the second dimension of belonging. Norms steering mutual expectations and obligations create common horizons in the here and now, stabilising them as norms of reciprocity, loyalty, and commitment. Mutuality means acknowledging the other which often results in compliance to rules ordering social relations (Simmel 1908, Weber 1921; Tyrell 2008). Families expect obedience and loyalty as well as pooling of resources. Associations and organisations expect participation, acceptance of common goals, and a sufficient contribution of time and resources. Belonging to a nation means sharing in a given polity's well-being and enjoying civic rights, while reciprocating via performing civic duties, in particular, by paying taxes. To enter a national space and durably remain, migrants need to present themselves as particularly deserving. Also cliques and friends jealously monitor a mutual allocation of obligations and debts. These calculations - that can be more overt or covert - result in 'regimes of belonging', that is institutionalised patterns insisting upon investments of time and resources, loyalty and commitments the 'prices' people have to pay for belonging together, and when these 'prices' are not paid, most collectives can resort to sanctions, such as exclusion or ostracism.

The unlikely term, 'regimes of belonging', combines the cosiness of the human forms of commonality, the warmth of communitarian existence, with its putative opposite, i.e. 'regime' as something authoritative and constricting. A 'regime' is, according to the political scientist Stephen Krasner (1982), a ,set of implicit or explicit principles, norms, rules, and decisionmaking procedures around which actors' expectations converge in a given area of international relations". Any self-imposed rules can be equally overwhelming and oppressive as those imposed by external rule. 'Own rules' within communitarian patterns can be even more imposing as consent and subjugation represent themselves as voluntary - i.e. voluntary acknowledgment of the authority and wisdom of the (often male) elders. In transnational immigrant regimes, the valid norms are forged by members of the national we-groups (Elwert 1997; Pfaff-Czarnecka 2009) that also extend to immigrants. Most newcomers usually do not fit into the national frameworks of values and norms and do not share cultural repertoires - at least in the perception of the autochthonous population. Under these conditions, forging civic commonality is an onerous process.

Both, social inclusion and social exclusion underlie regimes of belonging. All bounded collective units, e.g. states, ethnic and religious organisations, associations and families, make use of devices buttressing commonality, mutuality, and attachments while simultaneously excluding outsiders. States, in particular, have a tremendous regulatory force - guarding 
boundaries, regulating access criteria and the modalities of stay, and demanding the performance of numerous duties from denizens. Migrants coming to Western metropoles must show themselves to be 'deserving'. If they do not enjoy full citizenship rights, migrants endure a restricted set of rights while performing the full range of civic duties expected from people living in a given national territory. While paying taxes and when formally employed usually enjoying social rights at the place of destination, immigrants are incorporated into frameworks of generalised reciprocity (re-distribution of taxes), but are often denied creating attachments through restrictions of buying land and restrictions of displaying their 'being there' - as the Swiss debate of the minarets has revealed (Pfaff-Czarnecka 2009).

Regimes of belonging are not only structured by restrictive state rules, whereas, public opinion is often dominated by voices celebrating the inlanders' cultural authority in determining values and norms underpinning the national or local commonality. The more mistrust vis-à-vis aliens, the less public acknowledgment of their presence and the more suspicion that a migrant would not know how to socially navigate in his or her new home, the more cumbersome the process is of creating new belonging in a new place. "Your homeland is where you can offer criticism" - This phrase, formulated by a migrant of Greek origin living in Switzerland, perfectly brings to light the intricacies of belonging and the subtle power of immigration regimes.

\section{Attachments}

Attachments, the third dimension discerned here, follow different patterns in creating belonging (Pfaff-Czarnecka 2010). Attachments link people to material and immaterial worlds (Flinders 2002; hooks 2009). Attachments make people belong to spaces and sites, natural objects, landscapes, climates, and material possessions. These are forged through such disparate links as embodiment, resonance of smells and tastes (as with Marcel Proust's famous Madeleine) as well as rights and citizenship, and in particular, property rights. Growing up in a locality can create a strong sense of belonging - and so does the ownership of land or a house. Whenever people leave an airplane, they are told: 'take your belongings with you' - which brings one property of material attachments to light. It is difficult to forge attachments, but they can be created. Religious sites such as cemeteries and places of worship can be conducive here. Muslim immigrants have for instance created such places of attachment in many European places, but they usually had to struggle hard for this. Denying immigrants the right to erect visible religious structures marking their durable presence in the places of their arrival - as happened through the Swiss federal vote against the minarets - expressed the Swiss majority's reluctance to accept that Muslims could make Switzerland their new home. 
In their combination, commonality, mutuality, and attachments stabilise belonging, rendering collective sociability durable. They forge a strong and binding sense of naturalness that is obvious to the insiders and keeps the outsiders at bay. Claims to normality / naturalness of a given social order reduce complexity by clearly discerning between the inside and the outside. And this state of affairs is likely to institutionalise power relations governing the social life between and also within any given collective. Shared knowledge, practices and norms are products of sometimes restrictive social practices and of unequally distributed chances and resources. Therefore, belonging often comes at the price of subjugation vis-à-vis norms guiding and guarding the collective life. To put it simply: belonging can be cosy, but also exclusionary and oppressive. It almost always comes at a price.

\section{Creating belonging}

To belong in the modern world means to reflexively consider the meaning of home and a person's sense of place. Time and again, individual and collective belonging have been encroached upon, challenged, fought about, and protected. State rule, market forces, forced displacement, transnationalisation, pluralisation, acceleration of social change, and the widening horizon of human aspirations have rendered belonging contested from outside and from within. The more it is contested and made explicit, the less likely it is to just be and tacitly shared. The value, then, can lie in keeping one's protected space, often at the high price of self-subjugation under the governmentality of their own collective as well as at the price of excluding others. Also, people oftentimes, jealously guard the boundaries of the small world of their we-collective. The other option of belonging is to render the boundaries of the social permissible, creating space for negotiations of new and expanded meanings of mutuality and togetherness.

And yet there is another - highly interesting - property of belonging, namely, the possibility to forge new ties of collective boundedness. The concept of belonging provides a tool to inquire how horizons of togetherness are and can be widened to incorporate newcomers - how to extend collective we-understanding by including former strangers. In the climate of politically charged passions about belonging, social exclusion seems to be a norm in shaping relationships between we-groups and those considered outsiders. Nevertheless, throughout history all around the world, new constellations of belonging have been forged and will continue to come into existence in the future. Bounded and exclusive belonging becomes increasingly problematic, given the pluralising nature of contemporary societies and given the differentiated character of any given collective social space that the regimes of belonging seek to cover up. 


\section{The multiplicity of belonging}

So far, this text highlighted the bonding properties of belonging as they are found, for instance, in the common understanding of ethnic groups. But it is necessary to distinguish between ethnicity's (or nation's or a family's) selfrepresentations, on the one hand, and the properties of relations within collectivities, on the other. The multifaceted and dense concept of belonging allows us to disentangle collectivizing notions such as ethnicity for at least three reasons. First, from the point-of-view of social actors, belonging is always multiple. Any given constellation of boundedness competes with other constellations of belonging that vie with each other for membership and their members' commitments. Second, coming back to the distinction between 'belonging with' and 'belonging to', it is crucial to conceptualise belonging as created by individual persons in negotiated collective constellations, or put another way, how people navigate through the diverse constellations of belonging they encounter in their life-courses. Third, collectives are internally differentiated. Taking ethnicity as one life-world is highly misleading, given the internal plurality that accompanies the intersections of socio-economic differentiation, gender, spatial distribution, and internal subdivisions by language, dialect or religion as well as all kinds of personal orientations such as political leanings or sexuality - that may collide with community norms.

Belonging in today's world is a complex affair; ethnicity is a case inpoint. As soon as one goes beyond groupist representations, (to use Rogers Brubaker's concept) ethnic collectives are characterized by internal plurality. Within any given collective unit, everyone differs in his or her social location and positionality. Gender, socio-economic status, political networks, resources and convictions, geographic location, lifestyle and aspirations, skills, profession and organisational memberships, religion and other commitments make for internal differentiations as well as for a multiplication of personal spaces to which one belongs in any given moment.

The concept of belonging provides an analytical tool to see collective boundedness as structured by regimes of belonging, catering to, for instance, identity representations, while simultaneously pointing to the possibilities of moving across social boundaries as well as the options for negotiating their meanings. The discussion has been centred so far on the collective dimensions of belonging - be that nation-states, ethnic groups, associations, or families, all are acting as regimes of belonging. Exclusions, dichotomisations, particularist orientations and clearly delineated boundedness are important properties of such constellations, highly buttressed by identity politics. In order to understand how we-constellations widen their horizons and how they may render their boundaries permissible, it is important to reverse the point of observation and to grasp how people navigate between the diverse constellations of belonging over the courses of their lives. 
From the point of view of the individual, belonging is always multiple, and should be evident from the above discussion. Throughout the life-course, everyone copes with the interplay between commonality, mutuality, and attachment by living simultaneously and subsequently in diverse constellations of belonging. Some forms of collective boundedness are ascribed - such as within family or one's ethnic group; others are acquired such as belonging to a university, a class, or a profession. Some are more exclusive (family, religion) than others (a hobby-club). Some forms of belonging are easier to obtain than, say, naturalization in an immigrant country. Some forms of intersectionality are easier to combine than others think of a white male Anglo-Saxon American Protestant, on the one hand, and a well educated hijab-wearing Muslim in Dresden, on the other.

Over the course of time, everyone's belonging will shift. People go to school, study, learn a profession, and enter a working place. A person probably will marry or enter a partnership and from then on, less time is available for friends and relatives in the nuclear home. People acquire new status vis-à-vis their relatives and peers; they position themselves anew. Some passages in the life-course demand abandoning a former location of belonging. This especially holds true for people who are socially mobile: time and again people of low socio-economic status are accused of treachery by their former peers for climbing the social ladder. Elites usually do not suffer this kind of alienation. An underprivileged socio-economic background - the key dimension of inequality, besides gender and race - is likely to impose special restrictions upon an individual. The writer, Bruno Preisendörfer, described, using his own life as an example, how higher education can cause children of parents with little formal education to be alienated from the nuclear home. One of the many privileges of children from upper strata - besides the material benefits and the ability to combine cultural dispositions and to simultaneously move in different social spaces - is that they are not compelled to change milieu while acquiring higher education.

In today's world, (1) people can simultaneously belong to two or more countries; (2) they can change belonging while passing through different stages in life - changing age groups and passing through different stages of status. (3) There is a situational multiplicity - people divide their time between home, school, friends, hobbies, and religious organisations. (4) There are also diverse horizons of belonging: family, ethnic group, nation-state, and the world - and these horizons can coexist in a manner that is full of tensions.

Some forms of belonging are significantly more durable and constraining. The estates of the Middle Ages come immediately to mind as a form of social ordering leaving little room for manoeuvre. The Hindu caste society continues to be similarly restrictive, but some degree of social mobility is currently observable in India and Nepal. Some dimensions of collective 
boundedness such as ethnicity and religion appear to be perennial and overpowering upon individuals, but in fact, such ascriptive dimensions can be chosen by those individuals. It is an empirical question whether a person opts for engaging in ethnic activism, whether she strives to abandon or at least reduce her allegiance to the communal ties, or whether she is compelled to abide to communitarian rules having hardly any choice.

The personal navigation through the diverse constellations of belonging consists of more or less conscious choices. Also, people encounter more or less permissible or restrictive rooms for manoeuvre in the process of constructing the self when they develop new normative orientations, when they engage in negotiations and when they position themselves socially. Belonging is hard work, and means maintaining relations and displaying loyalty and commitment. Diverse belongings must be combined and are usually weighed against each other. For any person, it is a central question which constellations of belonging create new possibilities and which have rather restrictive effects. Today's societies are so heterogeneous that it is impossible to assess which forms of collective boundedness open doors and which erect tight boundaries, i.e. which forms of collective boundedness have an ,enabling' or a ,constraining' bearing upon people.

There is a myriad of tight boundaries and restrictions impacting personal navigation. Creating new belongings can be especially cumbersome. William Crowley (1999) describes belonging using the metaphor of a disco that people want to gain entry to. Outside, at the door of the disco, people queue asking to be allowed inside. Similar imaginary queues can be found at the borders of immigration countries. The aspirants are to present documents, then they are assessed regarding how they will fit in and they need some money. Whether they are deemed suitable will be evaluated through more or less explicit criteria. There is a significant disproportion between the 'inside' and the 'outside'. The more exclusive the entrance standards are and the more you stand in the cold, the more you desire access. And the opposite may be true as well. The Jewish comedian, Groucho Marx, once said that he would not want to join a club that was desperate enough to accept people like him.

But what if the club a person has entered does not want this person to leave? This is a frequent constellation. All kinds of minorities have faced such severe pressures that they close their ranks and jealously guard collective boundaries - e.g., ruling against exogamous marriage. Family offers protection, recognition, and warmth, but demands that members are firmly committed demanding loyalty, consensus, and often subordination. Clubs and organisations and all kinds of former peers accuse their members of dissidence, or even treachery, when they try to sever mutual ties, and oscillate in the direction of another life-world. 
It is therefore necessary to consider the challenges people face when trying to get out of "their" collective. Such situations are not unusual. Facing majoritarian challenges, minorities often feel compelled to guard their boundaries, from outside and from within. Minority members often face restrictions when opting for an exogamous marriage, when not abiding to communitarian norms (e.g. being homosexual) or when trying to lessen the confines of collective belonging by spatially moving away. Enjoying the warmth, solidarity and protection of one's nuclear home and / or the extended network of kinship comes at the price of loyalty, displays of consensus (often submission) and the pooling of resources. Remaining inside entails displays of being - or displays of pretending to be - alike, which poses particular problems for those who have partly moved into new social spaces, especially while acquiring higher education or when opting for alternative forms of living. 'Belonging together' restricts attempts at social boundary-crossing (Lamont 2002) from outside and from within. In the same vein, collective belonging is under siege from outside and from within.

On the one hand, the desire to 'belong to' confronts people with the rules of collective boundedness, of 'belonging with'. On the other hand, it is through personal navigation that constellations of 'belonging with' change their shape, and one effect of personal navigation is that collective boundaries may come under stress. Recent research on processes of collective boundarymaintenance has indicated how and when social boundaries are blurred and shifted, for example, in immigrant contexts, after individual mobility has coalesced into collective patterns. The major value of belonging research lies in its not taking collective boundedness for granted. By combining the dimensions of commonality, mutuality, and attachments it indicates social closures as well as the possibilities of their opening-up, rather than falling prey to methodological collectivism. The belonging approach indicates the tremendous tensions people endure while navigating between social and spatial worlds. It is obviously cosier and less dangerous to maintain a home where one's religious or ethnic identity is not questioned. Marwa El-Sherbini paid the ultimate price for somebody else's insecurity and inability to acknowledge that belonging is not fixed.

\section{Discussion: the embattled politics of belonging in the contemporary world}

Belonging is paradoxical due to a basic tension. On the one hand, belonging is something cosy, a condition that is taken for granted. People belong together when things go without saying. To belong in the modern world, on the other hand, means reflexively reconsidering home and one's sense of place. This means that a basic property of human life that was previously prescious due to its tacit property has become more and more overt and contested. Time and again, individual and collective belonging have been 
encroached upon, challenged, fought about, and protected. State rules, market forces, forced displacement, transnationalisation, pluralisation, acceleration of social change, and the widening horizon of human aspirations have rendered belonging contested - from outside and from within. The more it is contested and made explicit, the less people can just 'be', share, and join in. Thinking about one's belonging explicitely can result in defending the protected space against all kinds of intrusions.

Belonging, resonating in 'be-long-in', displays strong past-oriented, nostalgic connotations. As an object of political action, it is very much an element of the present. The concept also has a strong aspirational, futureoriented element. Kannabiran (2006) distinguishes between belonging and becoming, suggesting that political struggles thrive upon ideas indicating where a given collective is heading to and what it is aiming for. So far, this text has concentrated on personal navigation between different social spaces of belonging and the entailed politics of the self. But the past decades have also witnessed pronounced collective mobilisation coalescing into a different politics of belonging. At least three global trends have instigated these politics. The first trend has usually been depicted as a third wave of democratisation and was significantly buttressed by the fall of the Berlin wall and the inspiration provided by civic action in Eastern European countries. Almost simultaneously, civil society movements gained momentum in many parts of the globe. Previously colonized populations "have reversed the colonial flow from centre to periphery with increasing intensity" (Comaroff and Comaroff 2009: 46-7). Challenging established West-dominated normative orders, displaying alterity, and forcing the "problem" of difference into the public (ibid.) realm, collective activism has shifted from deeply subjugated positions to self-conscious positions reclaiming oppressed spaces of resistance (Kannabiran 2006). These movements have embarked on a challenging path, deploying techniques and technologies that are products of globality and transnationality (means of communication, networking), while organising against detrimental impacts of neo-liberalism. Large-scale infrastructural projects as well as the attempts of transnational corporations to secure intellectual property rights on items such as food grains or medicinal plants have greatly instigated the local sense of place and a spirit of local resistance (that I examined in my 'Challenging Goliath', see Pfaff-Czarnecka 2007).

The second trend buttressing collective politics of belonging came about with the global indigenous peoples' movement (see Pfaff-Czarnecka at al. 2007). This movement has reached a world-wide scope combining the politics of identity, entitlement, recognition and rights (Comaroff and Comaroff 2009: 47). This movement, initially carried out by the US-American and Canadian First People as well as by a growing number of ethnic activists in Latin American countries and in the Asian-Pacific region, has importantly 
gained in terrain with the establishment of the UN Working Group on Indigenous Populations in 1982 - this was followed by the Draft Declaration on the Rights of Indigenous Peoples by the ILO-Convention 169 as well as by the UNDRIP (UN Declaration of the Rights of Indigenous Peoples) http://www.un.org/esa/socdev/unpfii/en/drip.html. One important platform that helped in gaining momentum for indigenous politics arranged the Rioconference in 1992. The deliberations of this conference revealed the interconnection between the cultural (confining indigenous cultures to the private realm) and social dimensions (socio-economic and political power differentials and detrimental race politics) of indigenous peoples' existence within the territorial dimensions of space and place (confinement to societies peripheries; encroachment upon indigenous peoples lands). Both these trends have greatly instigated the collective politics of the self - i.e. modalities of agreeing upon common representations and developing practices of mutuality, geared indispensable toward pursuing projects of becoming (Kannabiran 2006). The politics of the self are embedded in the regimes of belonging and combine common visions of the future, entrepreneurship (or even 'ethnopreneurialism,' as Comaroffs, 2009, calls certain ethnic measures), measures of self-care as well as forms of self-fashioning buttressed by the idea of shared essence and common destiny. In this vein, they are important elements of governmentality.

The third trend comes with the transformative impact of neoliberalism (Comaroff and Comaroff 2009: 47) that has created newer and ever denser interconnections between different regions of the world, transpiring through financial flows as well as the displacement of production sites and workers. Important interconnections occur between countries "sending" and "receiving" migrants. These global, international, and transnational developments have greatly shaped societal change, impinging upon state's sovereignty, buttressing transnational social flows and exchanges, and challenging national we-group understandings.

Under these - often intersecting - conditions, a variety of politics of belonging came into existence, or - if they already existed before - gained public attention. The first form of collective 'politics of becoming' is currently and often depicted with a slightly confusing quest for 'social inclusion': collective mobilisation aimed at 'uplifting' a collective social position within a universally conceived social structure (Brubaker and Cooper 2000). Collective politics of belonging seek to abandon deeply subjugated social positions by generating new types of resources geared toward regaining the space of resistance and power. The language of rights has opened up new avenues for individual and collective mobility, be it the right to education (e.g. through quotas as in India), the right to different types of social welfare provisions, the right to self-determination (as in a number of South-East and 
Eastern European countries) or simply more rights for local participation and self-rule (through measures of decentralisation and devolution of power). The term 'social inclusion' is misleading in the very sense that a possibility of newcomers 'joining in' in established orders is implied by it - whereas, innumerable examples of social struggles reveal that 'social empowerment' is usually accompanied by a thorough transformation of any given society and its institutional orders.

The second type of politics of belonging, coming to light especially with indigenous activism, is largely driven by identity politics. Such politics are usually oriented toward the past, with the activists highlighting the common origins and genealogies as well as the reasons of having been there first, and the ensuing rights to particular territories. The politics of identity tend to highlight particularism, take recourse to strategic essentialism, cater to homogenising images of the collective self and thrive upon sharp ethnic boundaries that often discriminate between the collective we-groups and outsiders. Politics of identity turn into politics of belonging when collective mobilisation reaches beyond the contested space of identity representations. The indigenous politics of belonging struggle for political self-rule, reversing past wrongs such as encroachment on ancestral lands, and in doing so insist upon decentralising the realm of national political economic realms. In his most pertinent analysis of the perils of belonging, Peter Geschiere (2009) demonstrated how such forms of emancipatory action is likely to go hand-inhand with a problematic collective particularism, excluding others to such an extent that they are denied the right to dwell in territories claimed by a particular ethnic group. Geschiere's argument is all the more powerful as he draws a parallel between the particularist ethnic politics of belonging occurring in local realms of African national spaces and equally exclusivist we-group self-understandings voiced by claustrophobic voices in numerous Western immigrant societies. In both cases, the exclusivist politics of belonging have been buttressed by the infrastructure of identity politics, discriminating between insiders and outsiders, and erecting tight social boundaries around the collective units.

Against this backdrop, a third type of politics of belonging appears particularly crucial. This type of politics has recently been described in the literature of recent migration flows as well as political reconfigurations asserting alterity and recognising differences within the terms 'co-habitation' and 'conviviality.' Judith Butler, who coined the term 'co-habitation' stresses that we can no longer decide ourselves in regards to whom we are living with. We are therefore compelled to maintain the pluralist character of living together - which does not follow our own choice - active. Paul Gilroy (2004) argues in his 'Postcolonial melancholia' along similar lines. The ways of finding common ground in living together, despite differing identities, 
convictions, and forms of life, are multiple and, indeed, possible. The options for creating civic commonality stand in opposition to exclusivist national wegroup identity politics as they have prevailed in the assimilationist ethos used against new-comers. Currently, belonging is becoming an object of politicization. Protecting one's home, keeping migrants at bay, or engaging in rivalries regarding who is more deserving to make a place his or her home are all entailed in the politics of belonging. But the more boundary-constructions, boundary-restrictions and boundary-protections become part and parcel of global reflexivity, the more wide-spread the awareness of the possibilities to transcend and to mould boundaries and to create new possibile spaces for our living together.

This discussion reveals the complexity of the key notion of belonging: 'social location'. (This notion is strongly intertwined with, but cannot be reduced to, geographical location.) Having defined belonging as an 'emotionally charged social location', it was the intention of this text to suggest avenues for understanding belonging as combining different keydimensions of social existence and experience that significantly channel different forms of political action. According to Brubaker and Cooper, in identitarian theorizing, 'social location' is defined as a "position in a multidimensional space defined by particularist categorical attributes (race, ethnicity, gender, sexual orientation)" (2000:7). In instrumentalist theorizing, 'social location' describes a position in a universally conceived social structure,for example, a position in the market, an occupational structure, or a mode of production (ibid. - italics by the authors). The concept of belonging suggests that 'social location' is the combination of both aspects. After all, the social structures of contemporary societies evolved in a combination of diverse parameters and resources as well as capabilities (Sen 1999; Alkire 2010). The challenge of grasping the central features of the belonging concept is even greater given the fact that the contemporary self-reflexivity under the conditions of peoples' globalised and transnational experiences renders the human preoccupation with territorial space and local attachments particularly pertinent.

\section{Conclusion}

This article stressed the necessity to distinguish between the concepts of collective identity and belonging, while proposing the latter as a well-suited lens for grasping the dynamics of sociability in the contemporary world. It proposed avenues for thinking of human forms of togetherness by combining tacit and overt understandings and performances of commonality with practices of mutuality, loyalty, and commitments and with different forms of material and immaterial attachments. Bringing these different elements 
together provides a significantly denser and more dynamic vision of collective constellations than the concept of identity, alone.

The analysis addressed the problem of homogenisation and sharp boundary-drawing in social science research and also in diverse forms of national, ethnic, or religious activism. Contrary to many collectivist self representations and practices of othering, the concept of belonging helps in grasping the processes of moving, shifting and transcending the boundaries of the social. It provides social research with a tool to think about the social practices of negotiating collective boundedness understood to be in continuous flux, selection, and combination between diverse parameters of belonging.

This analysis revealed that belonging and boundaries are two sides of the same coin. As long as belonging remains tacit, boundaries may not be at the forefront of experiencing togetherness. When belonging is "what goes without saying', then the sense of togetherness is buttressed by what is shared in a given situation. In the present-day politics of belonging, however, boundaries, frontiers, and limits of the social acquire a central stage in human negotiations of their social locations in the world. As a heightened sense of belonging can result in manifold exclusions, humans can also shape their politics of becoming by creating belonging that is open-minded and inclusive.

\section{References}

1. Alkire, S. (2010). Conceptual Overview of Human Development: Definitions, Critiques, and Related Concepts. Oxford Poverty \& Human Development Initiative, Background paper for the 2010 Human Development Report (Download 19-09-2010).

2. Anthias, F. (2006). Belongings in a Globalising and Unequal World: Rethinking Translocations. In Yuval-Davis, N.; Kannabirān, K. \&, Ulrike Vieten (Eds.), The situated politics of belonging (pp. 17-31). SAGE.

3. Brubaker, R.; Cooper, F. (2000). Beyond "Identity". Theory and Society, 29(1), 1-47.

4. Comaroff, J. L.; Comaroff, J. (2009). Ethnicity, Inc. The University of Chicago Press.

5. Crowley, J. (1999). The Politics of Belonging: Some Theoretical Considerations. In Geddes, A. \&, Favell, A. (Eds.), The politics of belonging. Migrants and minorities in contemporary Europe (pp. 1541). Ashgate.

6. Elwert, G. (1997). Boundaries, Cohesion and Switching: On Wegroups in Ethnic-National and Religious Forms. In Wicker, H.-R. (Ed.). Rethinking Nationalism and Ethnicity. The Struggle for Meaning and Order in Europe (pp. 251-272). Berg. 
7. Flinders, C. L. (2002). The values of belonging. Rediscovering balance, mutuality, intuition, and wholeness in a competitive world. Harper.

8. Gerharz, E. \&, Pfaff-Czarnecka, J. (Eds). (2017). Spaces of Violence in South Asian Democracies. Special Issue at Asian Jounal of Social Science 45 (6).

9. Geschiere, P. (2009). The perils of belonging. Autochthony, citizenship, and exclusion in Africa and Europe. Chicago University Press.

10. Gilroy, P. (2004). Postcolonial melancholia. Columbia University Press.

11. Hooks, Bell (2009). Belonging. A Culture of Place. Taylor \& Francis. Jenkins, R. (1996). Social Identity. Routledge.

12. Kannabiran, K. (2006). A Cartography of Resistance: The National Federation of Dalit Women. In Yuval-Davis, N.; Kannabirān, K. \&, Vieten, U. (Eds.), The situated politics of belonging (pp. 54-73). SAGE.

13. Krasner, S. D. (1982). Structural Causes and Regime Consequences: Regimes as Intervening Variables. In International Organization 36(2) 185-205. Reprinted. In Krasner, S. D. (1983). International Regimes. Cornell University Press.

14. Lamont, M. \&, Molnár, V. (2002). The Study of Boundaries in the Social Sciences. Annual Review of Sociology 28, 167-195.

15. Luhmann, N. (1997). Die Gesellschaft der Gesellschaft. Suhrkamp.

16. Migdal, J. S. (2004). Mental Maps and Virtual Checkpoints. Struggles to Construct and Maintain State and Social Boundaries. In Migdal, J. S. (Ed.). Boundaries and Belonging. States and Societies in the Struggle to Shape Identities and Local Practices (pp. 3-27). Cambridge University Press.

17. Pfaff-Czarnecka, J. (1989). Macht und rituelle Reinheit. Das hinduistische System und ethnische Beziehungen im Entwicklungsprozess Nepals. Rüegger Verlag.

18. Pfaff-Czarnecka, J.; Nandy, A.; Rajasigham, D. \&, Gomez, T. (1999). Ethnic Futures. SAGE.

19. Pfaff-Czarnecka, J. (2007). Challenging Goliath: People, Dams, and the Paradoxes of Transnational Critical Movements. In Ishii, H.; Gellner, D. N. \&, Nawa, K. (Eds.). Political and Social Transformations in North India and Nepal. Social dynamics in northern South Asia 2, Japanese Studies on South Asia 6 (pp. 421526). Manohar.

20. Pfaff-Czarnecka, J.; Büschges, C.; Kaltmeier, O. \&, Hecker, F. (2007). Ethnisierung und De-Ethnisierung des Politischen. Aushandlungen um 
Inklusion und Exklusion im andinen und im südasiatischen Raum. In Büschges, C. \&, Pfaff-Czarnecka, J. (Eds.), Die Ethnisierung des Politischen. Frankfurt am Main (pp 19-63). Campus.

21. Pfaff-Czarnecka, J. (2009). Accommodating religious diversity in Switzerland. In Bramadat, P. \&, Koenig, M. (Eds.). International migration and the governance of religious diversity (pp. 225-257). McGill.

22. Pfaff, W. (2010). Migration und Theater. In Baviera, S. (Ed.), Das andere Gesicht (pp. 313-321). Verlag um die Ecke.

23. Sen, A. K. (1999): Development as Freedom. Knopf Press.

24. Simmel, G. (1908). Soziologie: Untersuchungen über die Formen der Vergesellschaftung. Duncker \& Humblot. Toffin, G. \&, PfaffCzarnecka, J. (Eds.). (2014). Facing Globalization in the Himalayas. Belonging and the Politics of the Self. SAGE.

25. Tyrell, H.; Heintz, B. (2008). Soziale und gesellschaftliche Differenzierung. Aufsätze zur soziologischen Theorie. VS Verlag für Sozialwissenschaften.

26. Weber, M. (1972 [1921]). Wirtschaft und Gesellschaft. C. B. Mohr.

27. Zolberg, A. R.; Woon, L. L. (1999). Why Islam is like Spanish: Cultural Incorporation in Europe and the United States. Politics \& Society 27(1), 5-38. 